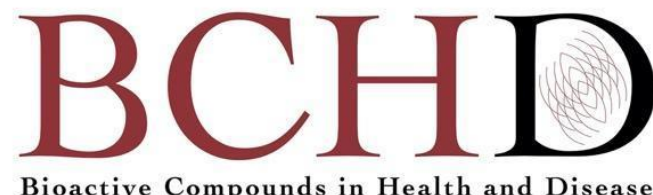

\title{
War as a separate and independent factor for rise in COVID-19 cases and death: how to use vitamins, and other bioactive compounds in the absence of vaccine
}

\author{
Katelynn Gilbert ${ }^{1,2 *}$, Benjamin Pitts ${ }^{1,4}$, Autumn Allen ${ }^{1,3}$, and Danik Martirosyan ${ }^{1}$
}

${ }^{1}$ Functional Food Center, Functional Food Institute, Dallas, TX, USA; ${ }^{2}$ Wilson College, Chambersburg, PA, USA; ${ }^{3}$ Michigan State University, East Lansing, Michigan, USA; ${ }^{4}$ Arizona State University, Tempe, Arizona, USA

*Corresponding author: Katelynn Gilbert, ${ }^{1}$ Functional Food Center, Functional Food Institute, Dallas, TX, USA and Wilson College, Chambersburg, PA, USA

Submission Date: November 25 ${ }^{\text {th }}$, 2020; Acceptance Date: December 21 ${ }^{\text {st }}, 2020$; Publication Date: December 28 ${ }^{\text {th }}$, 2020

Please cite this article as: Gilbert K., Allen A., Pitts B., Martirosyan D. Coronavirus concerns related to the war between Azerbaijan and Artsakh: War as a separate and independent factor for rise in COVID-19 cases and death: how to use vitamins, and other bioactive compounds in the absence of vaccine. Bioactive Compounds in Health and Disease 2020. 3(12): 256-273. DOI: https://www.doi.org/10.31989/bchd.v3i12.765

\section{ABSTRACT}

Background: COVID-19 is recognized as an acute upper respiratory disease. As the current COVID-19 pandemic nears the anticipated second wave of cases, many countries are struggling with tactics on how to limit the spread of the virus. With the emergence of conflict in the Artsakh region in late September, there has been a sharp rise in COVID cases both in this region and in surrounding countries that appears to be dissimilar from global transmission rates. This trend indicates that war could be acting as an independent and separate factor to COVID-19 spread in this area. With vaccines still in development, alternative methods of curbing the disease and its symptoms are of the utmost importance.

Methods: This article examines the historical context of war as a contributing factor in the spread of disease as well as the history of the Artsakh region. Comparing data gathered from the World Health Organization (WHO) on the conflicting region to case counts and death rates

HOW DOES WAR ACT AS A SEPARATE AND INDEPENDENT CONTRIBUTOR TO COVID-19 CASES?

UTILIZE DATA AND EDUCATIONAL RESOURCES TO HELP SLOW THE SPREAD OF COVID-19

PROVIDE CONTEXTUAL ARGUMENTS FOR WAR AS A CONTRIBUTING COVID-19 FACTOR

MATERIALS AND GUIDELINES FROM THE FFC CAN BE USED TO HELP MANAGE COVID-19 CASES.

WAR HAS BEEN FOUND TO BE AN INDEPENDENT AND CONTRIBUTING FACTOR TO COVID-19 CASES 
in neighboring countries and globally will reveal how transmission rates in this area may be different than others. A review of published literature on functional food ingredients to combat COVID-19 will also be used to frame guidelines and recommendations to reduce the spread of the virus.

Results and Conclusions: Based on data from the WHO on the Artsakh region, war appears to act as a separate and independent factor in COVID-19 transmission rates. To control the spread of COVID-19, it is important to eliminate war as a transmission factor by encouraging a ceasefire in areas of conflict and using materials and guidelines from the FFC to help control further spread. FFC guidelines include the use of functional food ingredients to mitigate intestinal and respiratory symptoms, while still promoting social distancing and the use of masks.

Keywords: COVID-19, Artsakh region, war, WHO, functional food, bioactive compound, Vitamin C, Vitamin D, zinc, folate, iron, selenium, copper

CFFC 2020. This is an Open Access article distributed under the terms of the Creative Commons Attribution 4.0 License (http://creativecommons.org/licenses/by/4.0)

\section{INTRODUCTION}

The novel coronavirus, COVID-19, began in December 2019 in Wuhan, China. Beginning early in 2020, cases began to rapidly increase in China before quickly spreading to Europe and the rest of the world. The first case in the United States was confirmed on January 21 and by March 11, the World Health Organization (WHO) officially declared COVID-19 a pandemic[1]. As the virus reached pandemic status, European countries experienced some of the highest numbers of total cases outside of China and the United States, including countries such as Spain and Italy[2]. As countries worldwide struggle to find the means to cope with the onset of the second wave of COVID-19 cases, there are also diplomatic issues that could influence a rise in cases in Europe. In this short review, we will describe the link between local war and COVID-19 as well as possibilities for spreading the COVID-19 infections in the whole region and worldwide. Methods of prevention and risk reduction using functional food ingredients as well as guidelines proposed by the FFC to combat COVID-19 will be reviewed in the absence of a vaccine.
Retrieval of Published Sources: A systematic review of news reports concerning the Azerbaijan and Artsakh conflict, as well as updated COVID-19 information and statistics was conducted electronically. Reputable sources used included the Los Angeles Times, the United Nations (UN), John Hopkins, the Center for Disease Control (CDC), New York Times, British Broadcasting Company (BBC), and National Broadcasting Company (NBC), where numbers of cases and deaths as well as updated information on the conflict were retrieved. [3-9]. A review of published sources concerning the use of functional food ingredients to combat the spread of COVID-19 was conducted utilizing PubMed and Google Scholar. Review and research papers were included, and published papers used are from the years 2019 and 2020. Keywords used for searching included: COVID-19, coronavirus, pandemic, vitamin C, vitamin, iron, copper, vitamin B, Azerbaijan, Artsakh, Armenia, conflict, nutrition, bioactive compounds, functional food, aging, 
immunity, risk, vitamin A, vitamin E, selenium, folate, prevention, vaccination, and zinc.

\section{Historical Comparison Between War and Pandemic}

Disease Spread: A historical comparison of these current events is the outbreak of the Spanish flu pandemic in 1918. While World War I had reached the tail end of its conflict by November, the Spanish flu reached pandemic status in February, creating an eight-month overlap period where almost as many United States soldiers died from the virus (about $45,000)$ than were killed in battle in the entirety of World War I $(53,402)[10,11]$. Between World War I, which would claim 20 million lives by its end, and the flu pandemic known as the Spanish Flu, which is estimated to have killed at least 50 million people, (including 675,000 Americans) the significant effects of war on the spread of disease is well-established [10]. Citing food shortages from the war, some scientists believe the poor quality of food that was being rationed also contributed to the growing pandemic [12]. Although it could be argued that COVID-19 does not have as severe a death rate as the Spanish flu due to the benefits of modern medicine, local governments face similar struggles of masking policies and business closures.

\section{Short Description of Conflict and History of Artsakh:}

The Nagorno-Karabakh (Artsakh) region has been under dispute for almost thirty years as an area that is officially recognized as a part of Azerbaijan but is largely controlled by ethnic Armenians. The early origins of this conflict can be traced back to the fall of the Russian Empire around 1918 when both the Azerbaijan Democratic Republic and the First Republic of Armenia gained independence [3]. Shortly after this, a brief conflict arose between the two countries, which was largely set aside as the newlyestablished Soviet Union gained control of the area. Then, when the Soviet Union dissolved in 1991 the area once again erupted into violence during the Artsakh War (1991-1994)[3]. While the Artsakh War officially ended in a ceasefire, there have been conflicts off and on for the last thirty years, leading up to the present-day issues. Recently, violence has once again flared up in this area as tensions rise in the middle of a global pandemic. On September 26, 2020, twenty-three people were killed as the two competing interests collided. As world powers such as Russia, France, and the United States try and fail to negotiate a ceasefire, COVID-19 becomes a rising issue in both Armenia and Azerbaijan and threatens to exacerbate the rising second wave of coronavirus cases in Europe.

Coronavirus Cases in the Conflicting Region: Since the conflict on September 26, there has been a steady increase in new daily cases in both Azerbaijan and Armenia. In Azerbaijan, daily new cases have risen from 108 on September 26 to 233 two weeks later on October 10, and up to 792 another two weeks later on October 24. While some of these cases could be attributed to external factors such as immune systems already compromised as flu season approaches and people are deficient in important vitamins and minerals, or colder temperatures driving people indoors, the reality is that people fighting and protesting in close proximity could easily result in a "super-spreader" event. This was seen in other viruses such as SARS and MERS, which also cause acute respiratory issues, one way to manage a super spreader event is the usage of bioactive lipids [13]. Bioactive lipids, when used against SARS and MERS, would envelop the virus therefore rendering them inactive [13]. This may help stop super spreader events from happening until a vaccine is widely used. Copper is also a good alternative to use as it also helps stop the spread of SARS and MERS, research is currently being conducted as to whether it would help stop the spread of COVID-19 as well $[14,15]$. 
Table 1. Confirmed Coronavirus Cases Over a Period of 11 Weeks (Data obtained from the World Health Organization) $[16,17,18]$

\begin{tabular}{|l|l|l|l|}
\hline \multicolumn{4}{|c|}{ Confirmed Coronavirus Cases Weekly Average } \\
\hline & Armenia & Azerbaijan & Global \\
\hline $9 / 07 / 20-9 / 13 / 20$ & 1,079 & 980 & $1,889,101$ \\
\hline $9 / 14 / 20-9 / 20 / 20$ & 1,569 & 870 & $2,043,583$ \\
\hline $9 / 21 / 20-9 / 27 / 20$ & 1,969 & 853 & $2,055,586$ \\
\hline $9 / 28 / 20-10 / 4 / 20$ & 3,096 & 666 & $2,065,990$ \\
\hline $10 / 5 / 20-10 / 11 / 20$ & 3,955 & 1,191 & $2,315,039$ \\
\hline $10 / 12 / 20-10 / 18 / 20$ & 8,243 & 2,565 & $2,501,382$ \\
\hline $10 / 19 / 20-10 / 25 / 20$ & 13,143 & 4,696 & $2,953,117$ \\
\hline $10 / 26 / 20-11 / 1 / 20$ & 14,417 & 6,256 & $3,420,465$ \\
\hline $11 / 2 / 20-11 / 8 / 20$ & 14,170 & 8,479 & $3,743,629$ \\
\hline $11 / 9 / 20-11 / 15 / 20$ & 10,913 & 9,681 & $4,026,466$ \\
\hline $11 / 16 / 20-11 / 22 / 20$ & 8,887 & 16,469 & $4,061,624$ \\
\hline & & & \\
\hline
\end{tabular}

Another possible reason for the rise in cases could be due to protests in both Armenia and Azerbaijan. In Georgia, while there is no direct involvement in the conflict, there have been several domestic protests held that undermine social distancing measures. In comparison, in Turkey, there has been a less dramatic increase in cases since they are not directly involved and there have not been any large-scale protests as seen in the aforementioned protests. While the rise in daily new cases in Armenia may not seem as dramatic as the increases seen in countries such as the United States, it must be taken into account the differences in the overall population, and how the current upward trend is creating all-time daily highs of new cases in Armenia and Azerbaijan even compared to the initial outbreak of the virus (see Figures 1 and 2). Figures 1 and 2 also show that even as global daily new cases (Figure 3) have continued to rise, previous use of masking and social distancing did allow for COVID-19 cases to subside in Armenia and Azerbaijan before this conflict began.

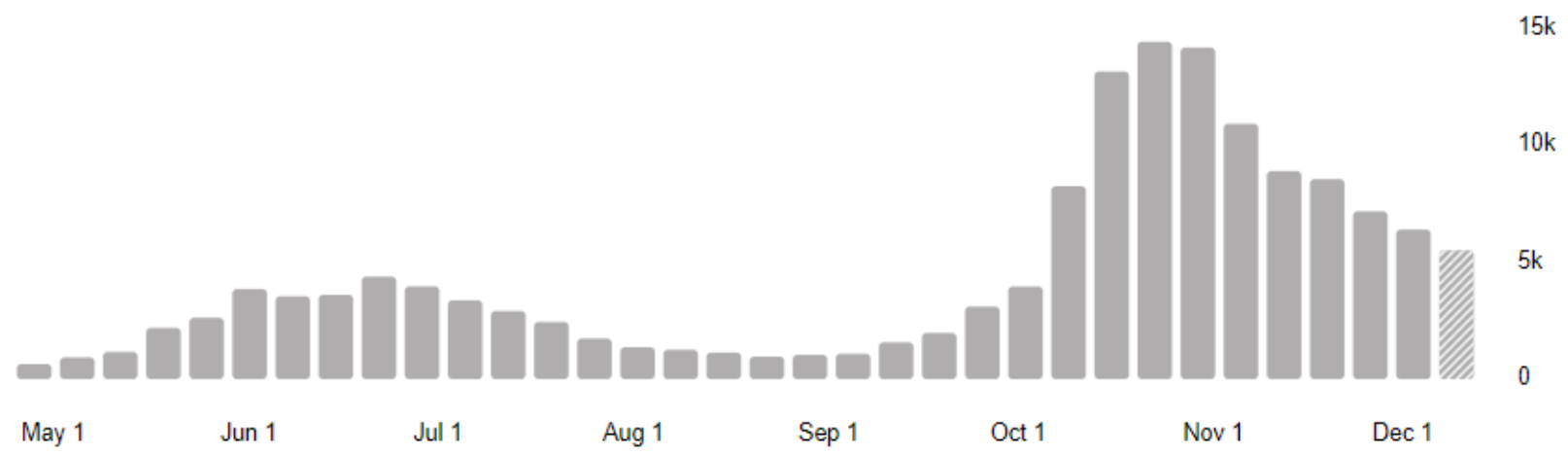

Figure 1a. Armenia Graph of Total Confirmed Cases as of December 20, 2020. Modified from the World Health Organization [16] 


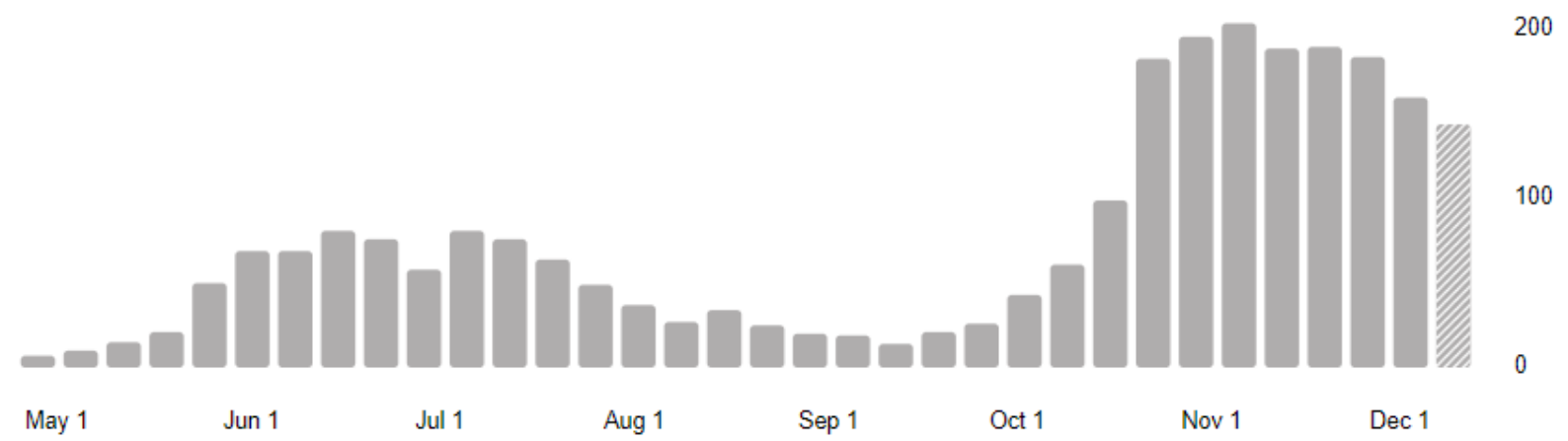

Figure 1b. Armenia Graph of Weekly Deaths as of December 20, 2020. Modified from the World Health Organization [16]

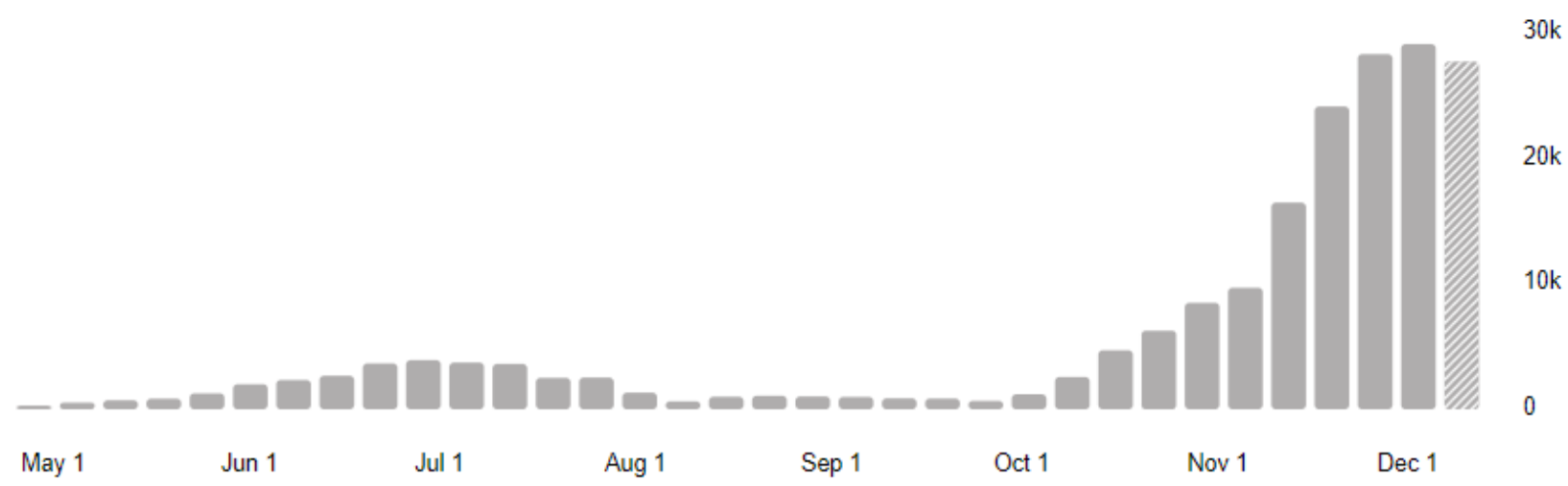

Figure 2a. Azerbaijan Graph of Weekly Confirmed Cases as of December 20, 2020. Modified from the World Health Organization [17]

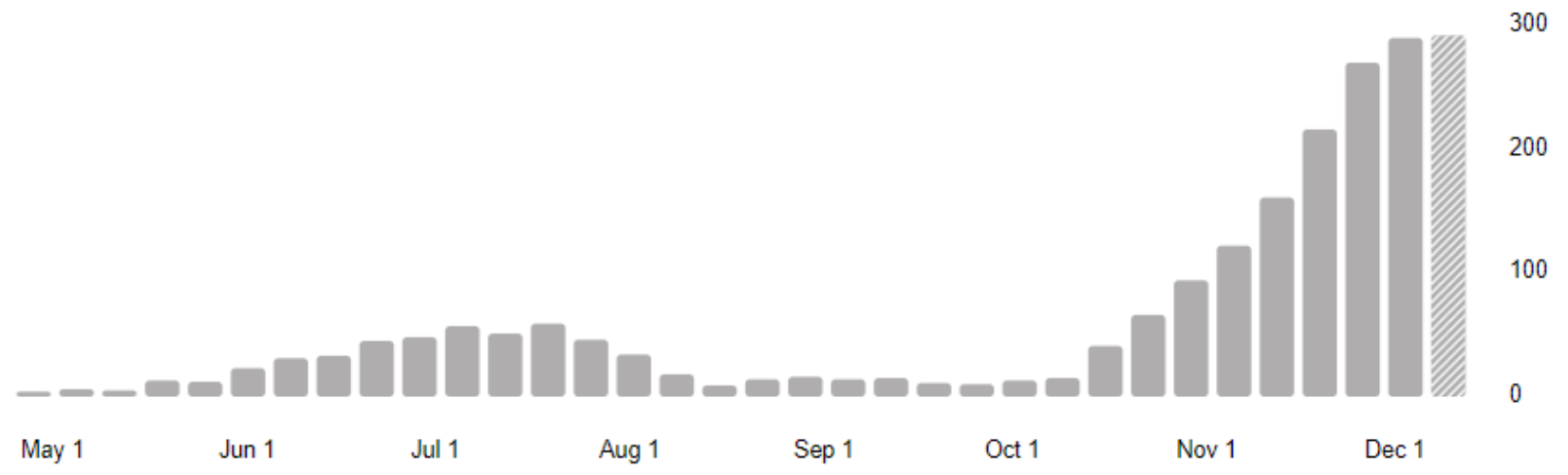

Figure 2b. Azerbaijan Graph of Weekly Death as of December 20, 2020. Modified from the World Health Organization [17] 
As deaths begin to accumulate, the long-term implications begin to compound and raise concerns over future population growth (Figures 1 and 2). These two figures provide a visual of the growth curve of deaths related to COVID-19 at different stages in Armenia and Azerbaijan. While both countries appeared to curb the spread and resultant deaths around July, it has been difficult to completely prevent COVID-19 deaths without many treatment options. That is why it is important to try to slow the spread of the virus as much as possible until a vaccine is produced and there are reliable treatment methods. This is the reason why the Functional Food Center evaluates and recommends functional food ingredients to boost the immune system and reduce symptoms. An example of a mineral that can help is zinc, this is due to zinc having the ability to help strengthen immune systems which in turn would have a better chance of fighting off COVID-19 [19].

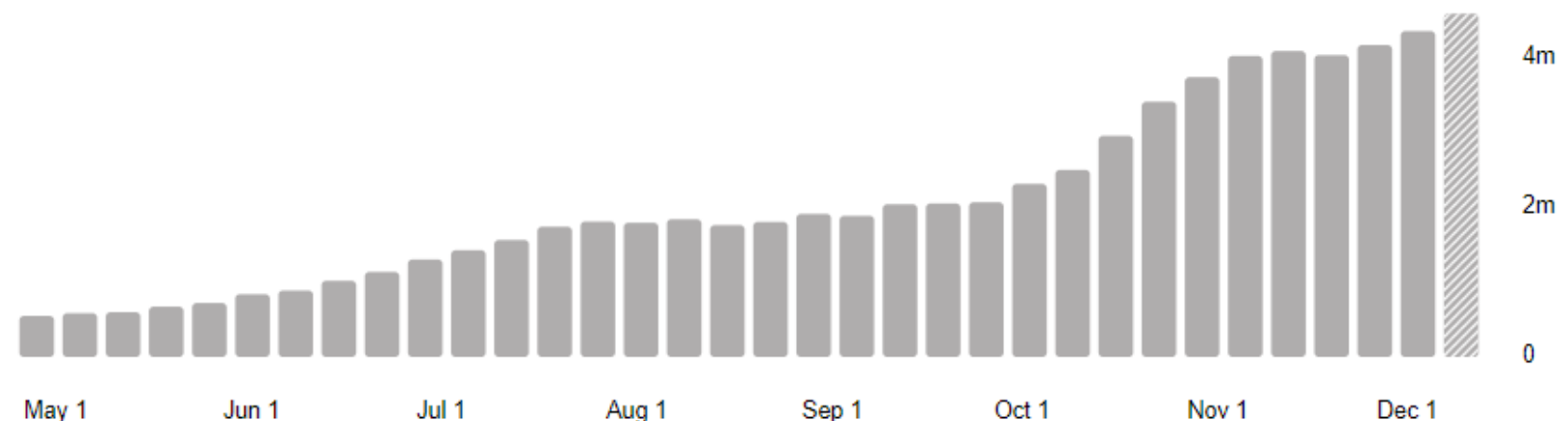

Figure 3a. Novel Coronavirus Global Weekly Confirmed Cases as of December 20, 2020. Modified from the World Health Organization [18]

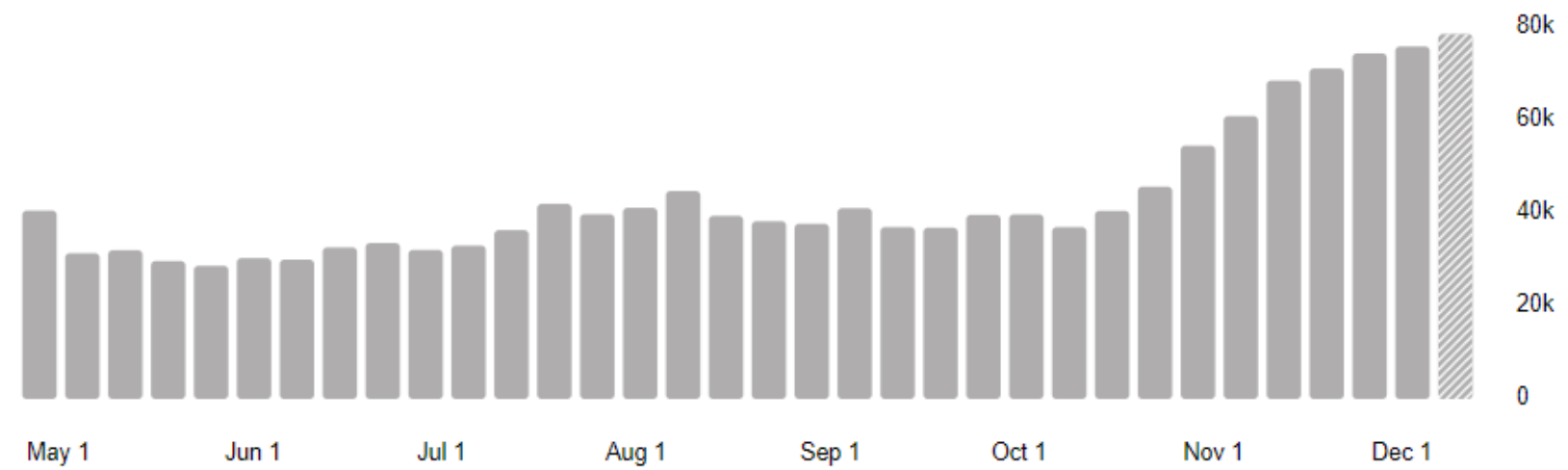

Figure 3b. Novel Coronavirus Global Weekly Deaths as of December 20, 2020. Modified from the World Health Organization [18]

Additionally, the impact that daily deaths (Table

2) have in countries such as Armenia and Azerbaijan compared to countries such as the United States is widely different considering the range in the overall population. As these deaths begin to accumulate, it poses long term concerns for the country's economic and social prospects. To an extent where this could begin to impact the country's ability to sustain its necessary infrastructure such as the healthcare system, and even everyday necessities such as gas, groceries, and other essential services. Minerals like selenium, which can help stimulate the immune system, may better protect essential workers from COVID-19 [20]. This in turn can help combat the downturn in infrastructure and help it bounce back sooner than if vitamin and minerals were not used. 
Table 2. Coronavirus Deaths Over a Period of 11 Weeks (Data obtained from the World Health Organization) $[16,17,18]$

\begin{tabular}{|c|c|c|c|}
\hline \multicolumn{4}{|c|}{ Daily Coronavirus Deaths Weekly Average } \\
\hline & Armenia & Azerbaijan & Global \\
\hline $9 / 07 / 20-9 / 13 / 20$ & 19 & 14 & 41,042 \\
\hline $9 / 14 / 20-9 / 20 / 20$ & 14 & 15 & 36,984 \\
\hline $9 / 21 / 20-9 / 27 / 20$ & 21 & 11 & 36,818 \\
\hline $9 / 28 / 20-10 / 4 / 20$ & 26 & 10 & 39,598 \\
\hline $10 / 5 / 20-10 / 11 / 20$ & 43 & 13 & 39,691 \\
\hline $10 / 12 / 20-10 / 18 / 20$ & 61 & 15 & 36,903 \\
\hline $10 / 19 / 20-10 / 25 / 20$ & 99 & 41 & 40,220 \\
\hline $10 / 26 / 20-11 / 1 / 20$ & 183 & 66 & 45,568 \\
\hline $11 / 2 / 20-11 / 8 / 20$ & 196 & 94 & 54,264 \\
\hline $11 / 9 / 20-11 / 15 / 20$ & 204 & 122 & 60,401 \\
\hline $11 / 16 / 20-11 / 22 / 20$ & 189 & 161 & 67,219 \\
\hline
\end{tabular}

While the total number of cases in Armenia and Azerbaijan is significantly less than larger countries such as the United States if you consider the number of cases in relation to the overall population it reflects the differences in the impact the caseload has. For example, the global rate of total confirmed cases per 1 million people as of September 12, 2020 was approximately 3,746 (Table 4). Azerbaijan, which on the same day had approximately 3,753, closely follows the global rate of confirmed cases (Table 4). However, Armenia had approximately 15,404 confirmed cases per 1 million population on this day, more than four times the global rate (Table 4). Similarly, when considering the number of deaths per 1 million population, the ratio of deaths in Armenia is still more than triple that of the global rate, and six times as much as that of Azerbaijan. This shows the impact that the recent rise in cases has had on the Armenian population, and that if the current trend continues the healthcare system could be stressed to its capacity. If this trend continues, not only could it have long term impacts for Armenia's population spread in the future, as total deaths per 1 million population also begin to rise (666 on November 23, 2020). Another concern as cases rise within the country is that the country could pass the point of a manageable number of cases, an infection could spread exponentially. It is for this reason that the current conflict, which is acting as an independent contributor to the rise of cases should be resolved as soon as possible before the threshold for manageable caseloads is overcome. 
Table 3. Total COVID-19 cases and total COVID-19 related deaths per 1 million population as of September $12,2020$. Data obtained from the World Health Organization [21].

\begin{tabular}{|l|l|l|l|}
\hline \multicolumn{2}{|l|}{ Comparison of Cases Per 1 million (M) Population as of September 12, 2020} \\
\hline & Total Cases per 1M & Total Deaths per 1M & Total Population \\
\hline Armenia & 15,404 & 307 & $2,965,154$ \\
\hline Azerbaijan & 3,753 & 55 & $10,170,444$ \\
\hline Global & 3,746 & 120 & $7,766,293,033$ \\
\hline
\end{tabular}

Table 4. Total COVID-19 cases and total COVID-19 related deaths per 1 million population as of November 23, 2020. Data obtained from the World Health Organization [21].

\begin{tabular}{|l|l|l|l|}
\hline \multicolumn{5}{|l|}{ Comparison of Cases Per 1 million (M) Population as of November 23, 2020} \\
\hline & Total Cases per 1M & Total Deaths per 1M & Total Population \\
\hline Armenia & 42,760 & 667 & $2,965,154$ \\
\hline Azerbaijan & 9,182 & 112 & $10,170,444$ \\
\hline Global & 7,486 & 177 & $7,827,478,395$ \\
\hline
\end{tabular}

War as an Independent Contributing Factor to COVID-19 Cases: In order to mitigate the spread of COVID-19 in the Caucasus region and Europe in general, it is in the best interest of world leaders to step in to help de-escalate the current conflict. Considering the interconnectedness of the world through international travel, this could also impact countries such as the United States, especially if the current conflict encourages residents of this area to seek asylum abroad. While a ceasefire may not be a long term solution to the root of the problems in this region, as history has shown, it is better than allowing the current conflict to remain unchecked and the spread of COVID-19 to increase through war and protest.

When taking into account the impacts of war on the spread of disease there are several factors to consider. For instance, during World War I, diseases such as influenza and pneumonia accounted for nearly 32,000 deaths and nearly $25 \%$ of the army fell ill to these same diseases at some point [22,4]. Even though modern conditions and medicine may be better than previous wars, there is still frequently a general compromise of sanitary conditions during wartime and between soldiers. In this manner, it is possible that soldiers that contract viral infections such as COVID-19 could cause an increase in casualties, especially in cases where soldiers may also be battling injuries. Also, if infection begins to spread in an encampment, proximity of living conditions for soldiers and shared resources could result in a rapid spread of cases. Finally, if the conflict in the region reemerges, the ability to dedicate resources solely to coronavirus management would be compromised.

Current conditions in Artsakh are somber. To shelter from artillery fire and other projectiles, both healthy and infected individuals are driven underground to wait out the conflict. Not only does this increase transmission of the virus itself, but it also hampers the ability of infected individuals to receive 
proper medical care, which could result in higher fatality rates. Similarly, healthcare workers are forced to work without proper personal protective equipment (PPE) to care for the wounded, which not only increases the spread among medical personnel and their patients but could also create personnel shortages in the near future. Without time, money, or resources contact tracing has effectively ground to a halt, further inhibiting officials' abilities to contain the spread of the virus [22]. Until the conflict in the Artsakh region is stabilized, it is unrealistic to expect that the current outbreak can be contained. This could significantly affect other countries in the region, as people could be moved into refugee camps in neighboring countries with sizeable Armenian populations such as Georgia and possibly as far as Western Europe and the United States. However, while war is a separate contributing factor to the rise in COVID-19 cases, other general factors that could exacerbate the onset of the second wave of COVID19. To try and negate the effects of a second curve, practices such as ones completed in Japan to flatten the first curve could be useful. It was found that when the body was already under previous mental or physical stress it was more susceptible to COVID-19 [23]. Fermented foods are a vital part of traditional Japanese food, which can contribute to an improved immune system [23].

Outside of the war-related spread of COVID-19, there are also general elements that could increase the number of COVID-19 factors. In the last few weeks, countries across the world have begun to see a sharp increase in COVID-19 cases as the anticipated second wave of COVID-19 approaches. One aspect of this oncoming second wave can be seen by evaluating the weekly global rise in new daily coronavirus cases. From September 19 to October 3, 2020, the new daily COVID-19 cases ranged from 301,695 to 304,567 to 305,131 . However, by October 10 , the number of global daily new cases had risen to 370,108 and has only continued to increase exponentially. For many countries, this second wave is showing higher daily caseloads than the initial outbreak of COVID-19. This could be due to many countries lifting coronavirus restrictions as cases appeared to reach manageable levels, having an unintended effect of causing more people to move away from social distancing and operate as though life had truly returned to normal [24]. Another contributing factor to this second wave could be an increase in the number of asymptomatic carriers of the virus. As people begin to spend more time together indoors as opposed to socially distancing at outdoor gatherings, the rate of transmission is increased.

Dietary patterns and habits can also impact the spread of COVID-19, as an adequate diet and nutrition are important for optimal immune response. Poor nutrition has been associated with inflammation and oxidative stress, which in turn result in an increased risk of infection [25]. Inflammation, caused by viral replication, has led to many complications in a severe acute respiratory syndrome that is caused by COVID19 and suggests a cytokine storm response [25]. A proper diet to reduce inflammation and oxidative stress contain adequate protein from glutamine and BCAAs, low saturated trans-fat, low refined sugars, high dietary fiber, and vitamins and minerals such as vitamins $A, C, D$, and zinc and selenium [25]. In Azerbaijan, obesity rates and other inflictions associated with inflammation such as type 2 diabetes and cardiovascular disease can be linked to excessively high energy food intake with decreased physical activity over the years [26]. These conditions make them more susceptible to infection due to a dysregulated immune system. When comparing death rates within European countries, there is an uneven distribution that may be due to different dietary patterns [27]. Regions with higher death rates were found to have higher fat-rich diets, while lower death rates were found in countries with high consumption of foods with potent antioxidant activity [27]. Shifting dietary patterns to include FFC recommended functional food ingredients can reduce inflammation and oxidative stress and 
promote a strong immune system, beneficial to fighting off COVID-19.

In addition to general concerns over coronavirus spread, unique problems arising with COVID-19. In the last few weeks, there have been reports of people who had already contracted COVID-19 becoming reinfected after recovery. This could pose issues towards the concept of herd immunity and threaten the mentality that while case numbers are currently high, these could dwindle as the number of uninfected individuals decreases. Unlike other viruses in the coronavirus family, it is still unknown what the antibody response to COVID-19 is and how immunity, or lack thereof, could affect transmission rates [5]. This could also affect the movement towards herd immunity. If affected individuals are unable to truly establish immunity, and without any concrete signs of a vaccine, mitigating practices such as social distancing and wearing masks could be the main strategies moving forward into the international second wave of COVID-19. This is why having knowledge of different vitamins, minerals, and bioactive compounds is important. Without knowing when everyone will be able to get vaccinated, it is important to try and lower your risk of contracting the virus through other means.

Another factor that arises as winter and colder weather approaches is the threat of secondary diseases. Lower solar UVB exposure in these winter months can cause Vitamin D deficiencies and lessen immune response [28]. While it has been generally recommended that everyone receive their flu shot this year, the seasonal flu could still pose a serious issue to the management of the second wave of COVID-19. Not only could it provide confusion when diagnosing early-onset since the symptomologies are so similar, but a combination of the two diseases could exacerbate patients' conditions and possibly increase death rates.

Similarly, the WHO could analyze the rise in cases in Armenia and Azerbaijan to develop targeted strategies to minimize spread. WHO could provide and distribute emergency equipment such as masks, sanitation supplies, and personal protective equipment (PPE) in order to control the current rise in cases from spreading to other European countries. The FFC would also recommend the distribution of functional food ingredients to increase the intake of critical vitamins and minerals that can slow the spread of the virus and improve immune response.

While countries such as the United States and the United Kingdom may feel as if this problem is remote, international protests speak to the contrary. For instance, on October 6 in Los Angeles, California hundreds gathered in just one of a series of protests within the city [6]. A similar protest was held in London in front of the prime minister's residence. These protests have helped raise international awareness of the issues in the Artsakh region and challenged world leaders to step in and attempt to de-escalate the situation. As a result of these efforts, a joint statement was released on October 25 that detailed a humanitarian ceasefire between Armenia and Azerbaijan cosponsored by the United States, Russia, and France. While the hope is that the ceasefire will persist at least until the virus is under control, the reality is that tensions remain high. Therefore, it is important moving forward to try to lower COVID-19 cases and deaths in case conflict once again break out. This is why the Functional Food Center finds it important to better explain how certain bioactive compounds, minerals, and vitamins could help reduce the risk of becoming infected and or more importantly help reduce the severe symptoms COVID-19 can bring.

United Nations Take on The War: COVID-19 has ravaged the world for months now. Before it was at its peak the United Nations (UN) Secretary-General Antonio Guterres on March 23rd urged countries to call for a cease-fire [7], so the world could fight the pandemic in unity. More than 180 countries took this advice to heart and ceased all fighting $[7,29]$, but this did not include Azerbaijan, one of the main conflicting 
parties. Secretary-General Antonio Guterres also highlighted how those impacted the most are defenseless women and children noting that "we must muster all our efforts to save lives and alleviate social and economic devastation on our peoples" [29]. On July 4, 2020, the UN spoke on how Sustainable Development Goals needed to be taken more seriously if there was to be as little impact as possible as countries move to a "new normal" [30]. During this announcement, it was noted that in Armenia and Azerbaijan there was still heavy weaponry use at the border resulting in several fatalities during this exchange [30]. When this news made it to the Secretary-General his full support went out to try to construct a peaceful settlement on the Artsakh conflict [30]. Yet on October 6, it was reported that there was a continuation of hostilities, and now populated areas were the main target [31].

In targeting these areas, artillery strikes began on September 27, which Azerbaijan initiated by attacking first so they could re-capture former territories that were taken by Armenia, as it was mentioned by the German Council on Foreign Relations [32]. As a result of these attacks, approximately 53 civilians, including children, have been killed as of October 8 [33]. This impacts many as now their way of sheltering in place is completely lost, leaving them vulnerable to COVID-19 as civilians find new shelter. High Commissioner for Human Rights, Michelle Bachelet has stated that this bloodshed is directly threatening the health of those affected during a pandemic [34]. This war is also not only being fought by Armenia and Azerbaijan, Turkey and Pakistan are aligned with Azerbaijan while France and Russia support Armenia [34].

In early October, a humanitarian cease-fire was announced for Armenia and Azerbaijan, yet to the dismay of many, this cease-fire was violated soon after as per what the UN Secretary General Antonio Guterres stated at one of the briefings [35]. Three cease-fires have now ended like this since the start of
September [36]. With more than 100 people injured, trauma kits began to be distributed in late October $[37,38]]$. As a result of the continued hostility, it was estimated in one month 130,000 people were misplaced, 76 kindergartens and schools were left in ruins, and 1 maternity was strafed [39]. With this mass displacement and lack of supplies converging together it has created a breeding ground for a super spread of COVID-19 across those who have little Aesculapian help. The government response has been shown to be an important factor in helping reduce the development of COVID-19 [40].

As of November 9, there has been an order for a cease-fire to all other conflicts in the NagornoKarabakh area [8]. This ceasefire was able to go through with the help of the Russian Federation overseeing the negotiations between the President of Azerbaijan, the Prime Minister of Armenia [8]. The Secretary General is very appreciative of the Russian Federation and all their help in this matter [8]. He has also emphasized that lasting peace will only continue if there are also peaceful settlements [8]. While the total number of deaths related to the recent conflict, both COVID-19 related and otherwise is still unknown, based on the data from the WHO and UN it could be as high as thousands.

Recent Developments: On November 11, 2020, Russia interceded to broker a peace deal between Armenia and Azerbaijan. Under the terms of the agreement, Azerbaijan gains control over any territory in the Artsakh region obtained during the recent conflict. While the leaders of both Armenia and Azerbaijan have agreed to this, it does not seem as though it will pose a long-term solution as this political and territorial loss will breed resentment for Armenian citizens. In order to maintain the terms of the treaty, Russia has deployed troops into the Artsakh region to discourage further outbreaks of violence [41]. In a recent press conference, the 
Armenian prime minister had the following to say about the peace treaty "This is not a victory but there is not defeat until you consider yourself defeated," which does not bode well for the long-term continuation of the peace treaty [42]. For this reason, the United Nations member countries need to continue to monitor the Artsakh region's geopolitical status and ensure that conflict does not re-emerge.

\section{FUNCTIONAL FOODS CENTER RECOMMENDATIONS}

To try and help lessen the spread of COVID-19 Functional Food Center has created recommendations. Some recommendations such as social distancing, mask wearing, and handwashing will be covered as per the government's orders. The advancements made in vaccinations and how the research for a cure has unfolded these past months and what a vaccination could mean for our future will be discussed as well. Functional Food Center will highlight vitamins and minerals, bioactive compounds, as well as functional foods that could help manage and reduce COVID-19 and the symptoms that follow. The care of the elderly population and how functional foods can help lower their risk is another section that will be covered. And lastly how to return to work safely and what measures companies, as well as schools will need to take to keep their communities safe from a second wave of COVID-19.

1. Social distancing, mask wearing and hand washing: Moving forward, the Function Foods Center has several recommendations to slow the spread of COVID-19. The following recommendations are derived from the Functional Food Center's 8th volume on Functional Foods and Viral Diseases and is a compilation of research from 33 scientists from around the globe. The full text provides information on the latest research related to COVID-19 and public health strategies to prevent the spread of the virus.
The primary method of limiting spread is to continue to evade exposure through social distancing and following health safety practices such as mask wearing and hand washing. Another measure is to ensure proper disinfection of common surfaces after use with at least a $60 \%$ alcohol sanitizer or all-purpose cleaner. If a person has been confirmed positive for COVID-19, individuals should quarantine, and contact tracing should be done to notify individuals that may have been in contact with the infected individual.

2. Vaccination: In March 2020, the U.S government-initiated Operation Warp Speed to rapidly produce a COVID-19 vaccine and other countermeasures. It has since provided \$10 billion in funding for development, manufacturing, and distribution to the most promising candidates [43]. The drug makers Pfizer and Moderna, as well as AstraZeneca who is working with Oxford, are in process of testing COVID-19 vaccines [44,9]. Oxford and AstraZeneca's vaccine is in the very early stages but has shown a similar immune response in people over the age of 56 and those between the age of 18 and 55 [44].

Pfizer, which recently released data from their Phase 3 clinical trials, and Moderna are looking to apply to the FDA to fast track the review process for what is known as emergency use authorization [9]. Pfizer and Moderna have also stated that, after Phase 3 trials, their vaccines are reporting 95\% effectiveness [44]. With the hope that a vaccine may be ready by the end of 2020, the U.S. Department of Health and Human Services has created a partnership with national and regional pharmacy chains to provide quick access to any approved vaccines [45].

As vaccines currently remain in development, another health strategy to 
pursue is the use of probiotics to address the gastrointestinal symptoms that people with COVID-19 have exhibited. Some reports are suggesting that SARS-CoV-2 RNA can be detected in the stool of those who have COVID19 [46]. This has led to the idea that the gutlung axis, cross-talk between the gut microbiota and the lungs, may have some involvement in COVID-19.

The use of various lactobacilli strains in COVID-19 patients has shown positive effects on SARS-CoV-2 induced gut dysbiosis which is responsible for gastrointestinal symptoms and diseases such as inflammatory bowel disease $[46,47]$. With emerging evidence of reinfection from the $\mathrm{Gl}$ tract reservoir of the virus, treatments to combat this reservoir and promote gut health is even more important. An enriched form of the Cameroonian Yellow Soup has shown promise in breaking down this reservoir and inhibiting viral replication in the GI tract [48].

3. Vitamins and COVID-19: In terms of specific healthy and functional foods, bioactive compounds (including vitamins, minerals, polyphenols, etc.), there are a variety of options for preventative care. One of the ways to support overall immune system health is by consuming an adequate number of micronutrients including vitamins $A, B 6, B 12, C$, $D$, and E. Not maintaining proper levels of these micronutrients can put individuals at an increased risk of contracting viral infections like COVID-19.

One vitamin that has been discussed in many articles is vitamin D. Vitamin D is known to inhibit the alteration of monocytes to macrophages, when stopping the transformation this helps regulate inflammation within respiratory issues [49]. Vitamin D can also raise the expression of two proteins known as TLR4 and TLR4 in monocytes, this helps uncover viral genomes [49]. Vitamin D also increases the production of antimicrobial peptides, which then can induce cathelicidin and defensin [50]. Vitamin $D$, in the proper plasma concentration of 50 $\mathrm{ng} / \mathrm{mL}$, is important for immune system responses during respiratory infections and helping the respiratory system inhibit virus replication [49]. Cathelicidin and defensin not only lower viral replication, but also reduce inflammatory cytokines [28]. The inflammation from these cytokines injures the linings of the lungs which can lead to pneumonia [28]. Those who may suffer from Vitamin D deficiency can reduce their risk of viral respiratory infections by taking vitamin $\mathrm{D}$ supplements to maintain proper circulating levels and benefit from the vitamin's inhibition of viral replication and anti-inflammatory properties. This is especially true during the winter season when 25(OH)D levels are low due to low solar UVB doses [28].

Vitamin A has also been shown to exhibit antiviral and anti-inflammatory effects through certain cell signaling pathways. Suppression of the MAPK signaling pathway is linked to anti-pneumonia effects of Vitamin A [51]. While further studies need to be done, vitamin A supplementation may act as an adjuvant to assist current clinical immunotherapies for treating COVID-19 [51]. Both vitamin B6 and B12 are also beneficial against inflammation. Pyridoxal 5'-phosphate (PLP), an active form of vitamin B6, has an inverse relationship with plasma IL6 which acts as a pro-inflammatory cytokine [52]. At the same time, it has shown to upregulate IL10, which is a powerful anti-inflammatory cytokine [52]. A recent study has given early evidence that supplementation of a combination of vitamin D, vitamin B12, and magnesium can reduce the number of COVID-19 patients that require oxygen support [53]. 
4. Relations of Functional Foods and Bioactive Compounds to COVID-19 Pandemic: Many functional foods are found to have important bioactive compounds. Such as the flavonoid quercetin, which is found in fruits and vegetables [54]. This bioactive compound is linked to the improvement of mental and physical performance and helps reduce the risk of infection [54]. The potential benefits for overall health and disease resistance include anti-inflammatory, antiviral, and antioxidant [54]. It was also noted in another article that having a diet full of proteins such as eggs, beans and peas, meat, poultry, seafood, processed soy products, nuts, and seeds [55]. When having a balanced diet that includes these foods the anti-inflammatory protein adiponectin will be present, this protein helps to break down fatty acids [55]. This is thought to help prevent COVID-19 infections as well as help treat and even improve a patient's outcomes [55]. Polyphenols have also been noted to have anti-inflammatory properties as it helps regulate both innate and adaptive immunity [56]. This is done through the modulation of different cytokines [56]. Polyphenols are able to find free radicals and other inactivated pro-oxidants and can also use their anti-inflammatory behaviors to inhibit the activation of NF-KB, and inducible nitric oxide synthases [56]. It can also inhibit pro-inflammatory enzymes such as cyclooxygenase-2, mitogen activated protein kinases, and protein kinase-C [56]. It was also found that the majority of herbal phenolic compounds could alter signaling and the enzymatic process that is involved in inflammation for instance tyrosine and serinethreonine protein kinases [56].

5. Minerals such as iron, copper, zinc, folate, selenium and COVID-19: Zinc is a good example of a mineral that while it does not carry direct antiviral resources, it can help with signaling antivirals by growing the body's interferon response [19]. This in turn can help the body better defend against viruses, such as COVID-19. Zinc can also have some authority in the antioxidant activity for some proteins [57]. Foods that are rich in zinc include blackberries, spinach, and green peas [19].

Consuming selenium is known to help stimulate the immune system, this will intensify activated T cells, and NK-cell activity [20]. When deficient in selenium this can cause the immune system to weaken and be more susceptible to attacks from COVID-19 [20].

Iron is another mineral that plays an important role. Iron is essential for the development and the conception of immune cells that can fight off COVID-19 like lymphocytes [14]. Iron also is known for its role in oxidative stress situations and can have strong antimicrobial effects [57]. To best absorb iron, it is recommended one consumes food rich in vitamin C as well [14].

Folate has been linked as a potential candidate to help prevent or treat COVID-19 and the beginning stages of respiratory issues [58]. Folic acid has also been noted to inhibit furin activity, which is a known enzyme for COVID-19 that can spike protein cleavage [59]. This mineral can be found in beans, oranges, and broccoli [58].

Lastly, there is copper, which has two important roles when helping fight off COVID19. The first is that copper helps the body better absorb and metabolize iron [58]. Copper also functions as a preventative measure to help stop the spread of respiratory viruses, such as SARS and MERS. Due to this much research has gone into whether this procedure would work for COVID-19 as well $[14,15]$.

6. Immunity, Aging Population, and COVID-19: Another method/approach, that is especially important for elderly individuals, is the consumption of at least five servings of fruits and vegetables. These fruits and vegetables can provide a partial source of micronutrients 
to bolster the immune system. This nutritional support is key to maintaining the health of critically ill patients.

Nutrition can significantly affect the rate of progression of COVID-19 but could also have an impact on secondary risk factors such as obesity. Oral feeding would be the ideal form of nutritional support for critically ill patients. However, if consuming fruits and vegetables directly for nutritional support is not a viable option, it is important to consider enteral feeding as the next possible option in order to deliver a formula that can specifically target symptoms and best support immune health [60].

Ensuring a healthy gut microflora and intestinal mucosa could help to mitigate symptoms such as abdominal pain and diarrhea, allowing for the amelioration of discomfort and possibly quicker recovery. A secondary effect of using probiotics to promote gastrointestinal health is an overall boost to the immune system, and specifically in preventing Upper Respiratory Tract Infections (URTI) characteristic of COVID-19 [60].

7. Return to Work: As the Artsakh region begins to restabilize and re-evaluate COVID-19 restrictions it is important to consider how to transition to return to school and work. The Functional Food Center recommends dealing with return to work with multiple strategic approaches. Educational institutions including public schools and universities should focus on continuing social distancing practices whenever possible by exploring virtual education models. For in-person instruction, both students and teachers should wear masks and space out as much as possible.

Another important consideration for these institutions is providing healthy, wellbalanced meals to help support the immune system. As the general public returns to work, businesses should set a plan for the anticipated "second wave" of COVID-19. This plan should include how to gradually reintroduce customers into the business or scale back, as the case may be. Additionally, sanitation policies should be put in place to decrease the risk of the spread of the virus and help to protect employees. More in-depth strategies and recommendations can be found within the Functional Food Center's textbooks (Textbook volume 1 and Textbook volume 8) as well as journal articles published in FFHD and BCHD.

\section{CONCLUSIONS}

To better control the spread of the oncoming second wave of COVID-19, it is important to eliminate war as a contributing factor. The World Health Organization recommends people isolate and socially distance as much as possible to reduce the risk of contracting COVID-19, but these precautions are difficult during times of conflict. Since the beginning of the new war in the Artsakh region, cases have sharply risen in both Armenia and Azerbaijan, to more than double the amount of daily new cases in periods as short as two weeks. Because of the lack of medical resources and living conditions during wartime, war becomes a strong, significant factor for spreading viral diseases such as coronaviruses. For this reason, the conflict in the Artsakh region should be resolved as quickly as possible so that attention can return to controlling the spread of COVID-19 before the number of infected individuals passes the threshold of manageable cases.

As cases in both Armenia and Azerbaijan rise, it is in these countries' best interest to reach a long-term resolution that will allow for the management of the similar dynamics of COVID-19 spread in these respective countries and permit officials to control the spread, so it more closely resembles global new case and death rates. To encourage world leaders to promote peace within this region, scientists and other officials should implore the UN to maintain the current peace treaty and combine resources (doctors, medical equipment, and testing kits) with the World Health Organization to assist with the management of the current outbreak. 
The President of the Russian Federation, the President of the United States of America, and the President of the French Republic, representing the Co-Chair countries of the OSCE Minsk Group, have condemned in the strongest terms the recent escalation of violence along the Line of Contact in the Artsakh conflict zone and called for an immediate ceasefire between Azerbaijan and ethnic Armenian forces living in Artsakh (Nagorno-Karabakh) [61]. Now, when the war is over, those representing the Co-Chair countries of the OSCE Minsk Group, as well as the United Nations and the World Health Organization (who is responsible for stopping the global spread of COVID-19), must assess why they were unsuccessful in preventing war during the pandemic. They must determine why some participants of the conflict did not respond to international calls for a ceasefire and thus hold them responsible for the accelerated spread of COVID-19 and the resulting loss of life. If this determination is not made, and no government is held accountable, then these organizations have failed in their duty and yet another catastrophe is certain to occur.

To assist with the situation related to infections in the conflict area, the Functional Food Center is able to share educational materials to better inform the general public about tactics for managing the spread of COVID-19 as well as provide more specific consultations over the usage of food, nutrition, vitamins, and trace elements to promote immune system health for all ages.

Abbreviations list: WHO: World Health Organization; PPE: Personal protective equipment; UN: United Nations; FDA: Food and Drug Administration; SARS: severe acute respiratory syndrome; MERS: Middle East respiratory syndrome; OSCE: Organization for Security and Co-operation in Europe

Authors' Contributions: All authors contributed to this article

Competing Interests: The authors declare no competing interests.
Acknowledgment: This research received no external funding.

\section{REFERENCES}

1. A Timeline of COVID-19 developments in 2020. [https://www.ajmc.com/view/a-timeline-of-covid19developments-in-2020] Retrieved November 20, 2020.

2. Hengbo Z., Li W., Ping N. The novel coronavirus outbreak in Wuhan, China. Global Health Research and Policy 2020; 5(6). DOI: https://doi.org/10.1186/s41256-020-00135-6

3. Armenia-Azerbaijan: Why did Nagorno-Karabakh spark a conflict?. [https://www.bbc.com/news/world-europe54324772] Retrieved November 20, 2020.

4. Centers for Disease Control and Prevention: 1918 Pandemic (H1N1virus). [https://www.cdc.gov/flu/pandemic-resources/1918pandemic-h1n1.html] Retrieved November 20, 2020.

5. Coronavirus second wave? Why cases increase. [https://www.hopkinsmedicine.org/health/conditionsand-diseases/coronavirus/first-and-second-waves-ofcoronavirus\#: :text=A\%20second\%20wave\%20could\%20s tart,the\%20fall\%20and\%20winter\%20months] Retrieved November 20, 2020.

6. Hundreds protest outside L.A. Times over coverage of Armenia-Azerbaijan conflict. Los Angeles Times 2020. [https://www.latimes.com/california/story/2020-1006/hundreds-protest-outside-l-a-times-building-overcoverage-of-armenians] Retrieved November 20, 2020.

7. Now is the Time for a Collective New Push for Peace and reconciliation [https://www.un.org/en/globalceasefire] Retrieved October 6th, 2020

8. De Waal T.: Great-power politics is back. The New York Times. $11 \quad$ November, 2020. https://www.nytimes.com/2020/11/11/opinion/armeniaazerbaijan-peace-deal.html Retrieved November 20, 2020.

9. Covid-19 vaccines could be available by the end of December. Here's what needs to happen first. [https://www.nbcnews.com/health/health-news/covidvaccines-could-be-available-end-december-here-s-whatn1248135] Retrieved November 19, 2020.

10. Worldwide flu outbreak killed 45,000 American soldiers during World War I.

[https://www.army.mil/article/210420/worldwide flu ou tbreak killed 45000 american soldiers during world w ar i\#: :text=American\%20combat\%20deaths\%20in\%20W orld,died\%20of\%20influenza\%20in\%201918] Retrieved November 20, 2020.

11. Department of Veteran Affairs: America's Wars. Office of Public Affairs 2019. [https://www.va.gov/opa/publications/factsheets/fs am ericas wars.pdf]. Retrieved November 20, 2020.

12. Martini, M., Gazzaniga, V., Bragazzi, N.L., Barberis, I. The Spanish Influenza Pandemic: a lesson from history 100 years after 1918. The Journal of Preventive Medicine and Hygiene 2019; 60(1): 64-67. DOI: https://doi.org/10.15167/24214248/jpmh2019.60.1.1205

13. Das, UN.: Can Bioactive Lipids Inactivate Coronavirus (COVID-19)?. Archives of medical research 2020; 51(3): 
282-286.

DOI:

https://doi.org/10.1016/i.arcmed.2020.03.004

14. Sharma, L. Dietary management to build adaptive immunity against COVID-19, Journal of PeerScientist 2020; 2(2): 1-6. DOI: https://doi.org/10.5281/zenodo.3774086

15. Raha S., Mallick R., Basak S., Duttaroy AK. Is copper beneficial for COVID-19 patients? Medical Hypotheses 2020; $142 . \quad$ DOI https://doi.org/10.1016/i.mehy.2020.109814.

16. World Health Organization: Armenia Health Emergency Dashboard [https://covid19.who.int/region/euro/country/am] Retrieved November 24, 2020.

17. World Health Organization: Azerbaijan Health Emergency Dashboard

[https://covid19.who.int/region/euro/country/az] Retrieved November 24, 2020.

18. World Health Organization: Global Health Emergency Dashboard [https://covid19.who.int/]Retrieved November 24, 2020.

19. Martirosyan, DM. The Emerging Potential of Functional Foods in Viral Disease Prevention. Functional Foods in Health and Disease 2020; 6(10): 95-99. DOI: https://doi.org/10.31989/bchd.v3i6.726

20. Singh, P., Tripathi, M.K., Yasir, M., Khare, R., Tripathi, M.K., Shrivastava, R. Potential Inhibitors for SARS-CoV-2 and Functional Food Components as Nutritional Supplement for COVID-19: A Review. Plant Foods for Human Nutrition 2020; 75: 458-466. DOI: https://doi.org/10.1007/s11130020-00861-9

21. World Health Organization: Health Emergency Dashboard Data Table [https://covid19.who.int/table?tableDay=yesterday] Retrieved November 24, 2020.

22. United States Foundation for the Commemoration of the World Wars: Diseases in World War I, Infectious Diseases. [https://www.worldwar1centennial.org/index.php/diseas es-in-world-war-

i.html\#: :text=Totals\%20for\%20the\%20AEF\%20were,com bat\%20deaths\%20during\%20the\%20war]

Retrieved November 20, 2020.

23. Tashiro, A. and Shaw, R.: COVID-19 pandemic response in Japan: what is behind the initial flattening of the curve? Sustainability 2019; 12(13): $5250 . \quad$ DOI: https://doi.org/10.3390/su12135250

24. Fighting accelerates COVID-19 spread in NagornoKarabakh. Bell Media. [https://www.cp24.com/world/fighting-acceleratescovid-19-spread-in-nagorno-karabakh-1.5153954] Retrieved November 20, 2020.

25. Iddir M, Brito A, Dingeo G, Fernandez Del Campo SS, Samouda H, La Frano MR, Bohn T. Strengthening the Immune System and Reducing Inflammation and Oxidative Stress through Diet and Nutrition: Considerations during the COVID-19 Crisis. Nutrients 2020; 12(6):1562. DOI: https://doi.org/10.3390/nu12061562.

26. Nikooyeh, B., Abdollahi, Z., Salehi, F., Nourisaeidlou, S., Hajifaraji, M., Zahedirad, M., Shariatzadeh, N., et al. Prevalence of Obesity and Overweight and Its Associated Factors in Urban Adults from West Azerbaijan, Iran: The National Food and Nutritional Surveillance Program
(NFNSP). Nutrition And Food Sciences Research 2016; 3(2): 21-26. DOI: https://doi.org/10.18869/acadpub.nfsr.3.2.21

27. Bousquet, J., Anto, J.M., laccarino, G., Czarlewski, W., Haahtela, T., Anto, A., Akdis, C., et al. Is diet partly responsible for differences in COVID-19 death rates between and within countries?. Clin Transl Allergy 2020; 10

28. Grant, W., Lahore, H., McDonnell, S., Baggerly, C., French, C., Aliano, J., and Bhattoa, H. Evidence that Vitamin D Supplementation Could Reduce Risk of Influenza and COVID-19 Infections and Deaths. Nutrients 2020; 12(4): 988. DOI: https://doi.org/10.3390/nu12040988

29. 170 signatories endorse UN ceasefire appeal during COVID crisis [https://news.un.org/en/story/2020/06/1066982] Retrieved October 6th, 2020

30. Highlights of the Noon Briefing by Stéphane Dujarric, Spokesman for Secretary-General António Guterres, Tuesday, $14 \quad$ July 2020 [https://www.un.org/sg/en/content/highlight/2020-0714.html] Retrieved October 6th, 2020.

31. Highlights of the Noon Briefing by Stéphane Dujarric, Spokesman for Secretary-General António Guterres Tuesday, $6 \quad$ October 2020. [https://www.un.org/sg/en/content/highlight/2020-1006.html] Retrieved October 6th, 2020

32. War in NagornoKarabakh A Two-Track Strategy for the EU, [https://www.ssoar.info/ssoar/bitstream/handle/docume nt/70139/ssoar-2020-racz-War in Nagorno-

Karabakh_a_Two-

Track.pdf?sequence=1\&isAllowed=y\&Inkname=ssoar2020-racz-War in Nagorno-Karabakh a Two-Track.pdf] Retrieved October $11^{\text {th }}, 2020$.

33. Highlights of the Noon Briefing by Stéphane Dujarric, Spokesman for Secretary-General António Guterres Friday, $9 \quad$ October 2020 [https://www.un.org/sg/en/content/highlight/2020-1009.html] Retrieved October 6th, 2020.

34. Analysis of Armenia and Azerbaijan War and its Impact on Both Countries Economies [https://www.researchgate.net/profile/Shah Fahad35/pu blication/344785826 ANALYSIS OF ARMINIA AND AZER BIJAN WAR AND ITS IMPACT ON BOTH COUNTRIES E CONOMIES/links/5f903f7f92851c14bcd881dc/ANALYSISOF-ARMINIA-AND-AZERBIJAN-WAR-AND-ITS-IMPACT-ONBOTH-COUNTRIES-ECONOMIES.pdf] Retrieved October $11^{\text {th }}, 2020$.

35. Highlights of the Noon Briefing by Stéphane Dujarric, Spokesman for Secretary-General António Guterres Monday, 12 October 2020 [https://www.un.org/sg/en/content/highlight/2020-1012.html] Retrieved October 6th, 2020.

36. Why violence has re-emerged in Armenia-Azerbaijan conflict [https://news.berkeley.edu/2020/11/06/whyviolence-has-re-emerged-in-armenia-azerbaijan-conflict/] Retrieved October 6th, 2020.

37. UN Secretary-General's Spokesman - on the situation between Armenia and Azerbaijan [https://www.un.org/sg/en/content/sg/statement/202010-25/un-secretary-generals-spokesman-the-situationbetween-armenia-and-azerbaijan] Retrieved October 6th, 2020. 
38. Highlights of the Noon Briefing by Stéphane Dujarric, Spokesman for Secretary-General António Guterres Tuesday, $\quad 27 \quad$ October 2020 [https://www.un.org/sg/en/content/highlight/2020-1027.html] Retrieved October 6th, 2020

39. Highlights of the Noon Briefing by Stéphane Dujarric, Spokesman for Secretary-General António Guterres Wednesday $28 \quad$ October 2020 [https://www.un.org/sg/en/content/highlight/2020-1028.html] Retrieved October 6th, 2020

40. COVID-19 Outbreak in Post-Soviet States: Modeling the Best and Worst Possible Scenarios [https://www.researchgate.net/profile/Yerlan_Amanbek/ publication/340863073 COVID-19 Outbreak in PostSoviet States Modeling the Best and Worst Possible Scenarios/links/5ea17986458515ec3aff8805/COVID-19Outbreak-in-Post-Soviet-States-Modeling-the-Best-andWorst-Possible-Scenarios.pdf] Retrieved October 6th, 2020.

41. BBC News: Armenia, Azerbaijan and Russia sign NagornoKarabakh peace deal. [https://www.bbc.com/news/worldeurope-54882564] Retrieved November 20, 2020.

42. Note to Correspondents: Nagorno-Karabakh [https://www.un.org/sg/en/content/sg/notecorrespondents/2020-11-13/note-correspondentsnagorno-karabakhl Retrieved November 20, 2020

43. Fact Sheet: Explaining Operation Warp Speed What's the goal? [https://www.hhs.gov/coronavirus/explainingoperation-warp-speed/index.html] Retrieved November 20, 2020.

44. HEALTH AND SCIENCE Oxford-AstraZeneca Covid vaccine shows robust immune response among older adults. [https://www.cnbc.com/2020/11/19/oxford-covidvaccine-prompts-immune-response-among-all-adultsstudy.html] Retrieved November 19, 2020.

45. Trump Administration Partners with Chain and Independent Community Pharmacies to Increase Access to Future COVID-19 Vaccines (2020) [https://www.hhs.gov/about/news/2020/11/12/trumpadministration-partners-chain-independent-communitypharmacies-increase-access-future-covid-19vaccines.html] Retrieved November 20, 2020.

46. Dhar, D. and Mohanty, A. Gut microbiota and Covid-19possible link and implications. Virus Research 2020; 285. DOI: https://doi.org/10.1016/i.virusres.2020.198018

47. Sundararaman, A., Ray, M., Ravindra, P., and Halami, P. Role of probiotics to combat viral infections with emphasis on COVID-19. Applied Microbiology and Biotechnology 2020; 104: 8089-8104. DOI: https://doi.org/10.1007/s00253-020-10832-4

48. Oben, J., Bigoga, J., Takuissu, G., Teta, I., and Leke, R. The acceptability (Star Yellow) a Cameroonian functional food that could curb the spread of COVID-19 via feces. Functional Foods in Health and Disease 2020; 10(8): 324329. DOI: https://doi.org/10.31989/ffhd.v10i7.715

49. Pezeshki S., Hashemi P., Mirmiranpour H. Vitamin D Effects on Immune Response Against Covid-19 and Influenza Infection: A Review. Bioactive Compounds in Health and Disease 2020; 6(10): 100-108. DOI: https://doi.org/10.31989/bchd.v3i6.724
50. Giordano C., Martirosyan D. The effects of vitamin D on respiratory illnesses: a prospective natural treatment for COVID-19 symptoms. Bioactive Compounds in Health and Disease 2020; 3(8): 124-140. DOI: https:/doi.org/10.31989/bchd.v3i8.734

51. Li R, Wu K, Li Y, Liang X, Tse WKF, Yang L, Lai KP. Revealing the targets and mechanisms of vitamin $A$ in the treatment of COVID-19. Aging 2020; 12(15): 15784-15796. DOI: https://doi.org/10.18632/aging.103888

52. Mikkelsen, K., Prakash, M., Kuol, N., Nurgali, K., Stojanovska, L., Apostolopoulos, V. Anti-Tumor Effects of Vitamin B2, B6, and B9 in Promonocytic Lymphoma Cells. International Journal of Molecular Sciences 2019; 20(15). DOI: https://doi.org/10.3390/iims20153763

53. Tan, C., Ho, L., Kalimuddin, S., Cherng, B., Teh, Y., Thien, S., Wong, $\mathrm{H}$., et al. Cohort study to evaluate the effect of vitamin D, magnesium, and vitamin B12 in combination on progression to severe outcomes in older patients with coronavirus (COVID-19). Nutrition 2020; 79-80. DOI: https://doi.org/10.1016/j.nut.2020.111017

54. Haslberger, A.G., Jacob, U., Hippe, B., Karlic, H. Mechanisms of Selected Functional Foods Against Viral Infections with a View on COVID-19:Mini Review. Functional Food in Health and Disease 2020; 10(5): 195209. DOI: https://doi.org/10.31989/ffhd.v10i5.707

55. Polamarasetti P., Martirosyan, D. Nutrition Planning During the COVID-19 Pandemic for Aging Immunity. Bioactive Compounds in Health and Disease 2020; 3(7): 109-123. DOI: https://doi.org/10.31989/bchd.v3i7.733

56. Rastmanesh R, Marotta F, Tekin I.:Call for mobilization of functional foods, antioxidants, and herbal antivirals in support of international campaign to control coronavirus Bioactive Compounds in Health and Disease 2020; 3(5): 9094. DOI: https://doi.org/10.31989/bchd.v3i5.717

57. Galmés, S., Serra, F., Palou, A. Current State of Evidence: Influence of Nutritional and Nutrigenetic Factors on Immunity in the COVID-19 Pandemic Framework. Nutrients 2020; 12(9): 2738. DOI: https://doi.org/10.3390/nu12092738

58. Sheybani, Z., Dokoohaki, M. H., Negahdaripour, M., Dehdashti, M., Zolghadr, H., Moghadami, M., Masoompour, S. M., Zolghadr, A. R. The Role of Folic Acid in the Management of Respiratory Disease Caused by COVID-19. ChemRxiv 2020.2 DOI: https://doi.org/10.26434/chemrxiv.12034980.v1

59. Mousavi, S.Z., Rahmanian, M., Sami, A. A connectivity map-based drug repurposing study and integrative analysis of transcriptomic profiling of SARS-CoV-2 infection Infection, Genetics and Evolution 2020; 86. DOI: https://doi.org/10.1016/i.meegid.2020.104610

60. Martirosyan DM., Santoro A., Malcolm S.: From Functional Foods and Viral Diseases: Enhancing the Eldery's Immune System for Healthy Aging, to Fight Chronic and Virals Diseases Including Covid-19. Volume 8 1st edition. Edited by Martirosyan DM. Food Science Publisher

61. Turkey rebuffs Russia, France and U.S. over NagornoKarabakh ceasefire moves https://www.reuters.com/article/us-armeniaazerbaijan/turkey-rebuffs-russia-france-and-u-s-overnagorno-karabakh-ceasefire-moves-idUSKBN26M5IJ. Retrieved November 22, 2020 